\title{
ZINK EFEKTIF MENGATASI DIARE AKUT PADA BALITA
}

\author{
Maria Ulfah ${ }^{1,2 *}$, Yeni Rustina ${ }^{3}$, Dessie Wanda $^{3}$ \\ 1. AKPER Pemerintahaan Kota Tegal, Jawa Tengah 52472, Indonesia \\ 2. Program Studi Magister Fakultas Ilmu Keperawatan Universitas Indonesia, Depok 16424, Indonesia \\ 3. Fakultas Ilmu Keperawatan Universitas Indonesia, Depok 16424, Indonesia \\ *Email: ulfahmaria83@yahoo.com
}

\begin{abstract}
Abstrak
Diare merupakan salah satu penyebab utama kematian pada bayi dan anak-anak di Indonesia. Tujuan penelitian ini adalah untuk mengidentifikasi efektifitas pemberian zink dalam mengatasi diare akut pada balita di salah satu puskesmas di Kalimantan Barat. Penelitian ini menggunakan desain kuasi eksperimental dengan jenis nonequivalent control group after only design. Jumlah sampel berjumlah 40 anak balita yang dibagi menjadi dua kelompok. Hasil penelitian menunjukkan adanya perbedaan yang signifikan pada frekuensi defekasi dan durasi diare pada kedua kelompok $(\mathrm{p}=0,000 ; \alpha=0,05)$. Jadi dapat disimpulkan bahwa pemberian zink efektif untuk menangani diare akut pada balita sehingga dapat mencegah akibat lanjut dari diare.
\end{abstract}

Kata kunci: balita, diare, durasi, frekuensi, zink

Abstract

Diarrhea is one of the major causes of infant and child death in Indonesia. The purpose of this research was to identify the effectiveness of zinc supplementation for acute diarrhea in under five years children in one puskesmas in Kalimantan Barat. The research employed quasi experimental with nonequivalent control group after only design. The samples were 40 participants which were divided into two groups. The result showed that there was significant differences in defecation frequency and duration of diarrhea in both group $(p=0.000 ; \alpha=0.05)$. To conclude, zinc supplementation was effective for acute diarrhea treatment in under five years children.

Keywords: under five children, diarrhea, duration, frequency, zinc

\section{Pendahuluan}

Diare akut merupakan penyakit yang sering terjadi pada anak berusia di bawah lima tahun, yang didefinisikan sebagai peningkatan secara tiba-tiba frekuensi dan perubahan konsistensi feses. Perubahan tersebut sering kali disebabkan oleh agen infeksius pada saluran pencernaan. Diare akut biasanya berlangsung tidak lebih dari 14 hari dan membaik tanpa penanganan spesifik jika tidak disertai dengan dehidrasi (Hockenberry \& Wilson, 2009).

Kemajuan terbesar dalam menurunkan angka kematian akibat diare yang diperkenalkan World Health Organization (WHO) adalah penggunaan cairan rehidrasi oral (Oral Rehydration Solution/ ORS). Cairan tersebut dapat digunakan untuk menangani gastroenteritis akut untuk pemeliharaan rehidrasi, dan mencegah komplikasi lebih lanjut akibat diare (Ladinsky, et al, 2000). Cairan rehid- rasi oral tersebut terbukti dapat mengatasi dehidrasi ringan hingga sedang pada bayi dan anak-anak secara aman, efektif, relatif lebih murah, dan mudah digunakan. Oleh karena itu, American Academy of Pediatric (AAP) dan WHO merekomendasikan cairan tersebut sebagai tindakan pertama untuk mengatasi dehidrasi ringan (Ladinsky, et al, 2000).

Namun, cairan rehidrasi oral tidak signifikan dalam menurunkan defekasi dan durasi diare (Lukacik, Thomas, \& Aranda, 2008). Oleh karena itu, WHO dan UNICEF kembali merekomendasikan kebijakan terbaru mengenai penatalaksanaan diare pada anak, yaitu dengan menambahkan suplementasi zink (Zn) pada terapi rehidrasi oral tersebut. Pemberian zink direkomendasikan untuk pengobatan diare selama 10-14 hari karena terbukti bahwa pemberian zink selama dan sesaat setelah diare dapat menurunkan tingkat keparahan dan durasi diare, 
serta menurunkan kemungkinan munculnya kembali diare pada 2-3 bulan setelahnya (Indriani \& Asri, 2007).

Kaitan antara zink dan diare telah dilaporkan melalui hasil penelitian epidemiologis maupun laboratorium. Diare akut pada anak di negara berkembang sebagian besar yakni diare infeksi. Zink mempunyai efek terhadap beberapa enterosit dan sel imun yang berinteraksi dengan agen infeksius pada diare. Zink utamanya bekerja pada jaringan dengan kecepatan turnover yang tinggi seperti halnya pada saluran cerna dan sistem imun dimana zink dibutuhkan untuk sintesa DNA dan sintesa protein (Bijleveld, et al., 1997, dalam Armin, 2005).

Data awal yang penulis dapatkan di salah satu wilayah kerja puskesmas di Kalimantan Barat bahwa pemberian zink pada anak yang menderita diare belum optimal dilaksanakan, dimana angka kesakitan akibat diare masih cukup tinggi dan penderita paling banyak adalah anak berusia di bawah 5 tahun. Oleh karena itu, penulis tertarik untuk mengetahui tingkat efektifitas zink dalam mengatasi diare akut pada balita di wilayah kerja salah satu puskesmas di Kalimantan Barat. Tujuan penelitian ini adalah diidentifikasinya gambaran tingkat efektifitas pemberian zink dalam menangani diare akut pada anak.

\section{Metode}

Penelitian telah dilakukan dengan menggunakan desain kuasi eksperimental secara nonequivalent kontrol group, after only design. Pengambilan sampel dalam penelitian ini dilakukan dengan cara non probability sampling dengan metode consecutive sampling, yaitu setiap anak yang memenuhi kriteria penelitian diikutsertakan sebagai sampel penelitian sampai kurun waktu tertentu sehingga jumlah sampel yang diperlukan terpenuhi. Pemilihan sampel didasarkan pada pertimbangan kriteria inklusi dan ekslusi yang dibuat oleh peneliti. Sesuai dengan kriteria yang telah ditentukan, didapatkan jumlah responden berjumlah 40 orang yaitu 20 responden untuk ke- lompok intervensi dan 20 responden untuk kelompok kontrol.

Kriteria responden dalam penelitian ini adalah anak usia 6 bulan hingga 5 tahun yang berkunjung ke puskesmas karena diare yang berlangsung kurang dari 14 hari serta tidak mengalami penyakit berat/ penyakit penyerta. Selain itu, ibu/ pengasuh bersedia berpartisipasi dalam penelitian, mampu membaca dan menulis, mampu berkomunikasi secara verbal dan non-verbal, dan bersedia melakukan intervensi yang dianjurkan kepada anak.

Alat pengumpul data dalam penelitian ini berupa kuesioner tentang karakteristik responden, dan lembar observasi responden untuk mengidentifikasi frekuensi defekasi dan durasi diare. Karakteristik responden meliputi: usia anak, status gizi anak, status pemberian ASI dan tingkat pendidikan ibu.

Lembar observasi responden berisi catatan mengenai kejadian diare pada anak setiap hari dan kepatuhan ibu dalam memberikan intervensi. Lembar observasi tersebut diisi sendiri oleh ibu responden. Peneliti melakukan evaluasi melalui kunjungan rumah yang dilakukan pada hari-7 dan hari14. Apabila pada hari-7, anak telah sembuh dari diare maka lembar observasi dikumpulkan pada hari itu juga, tetapi bila diare masih berlangsung peneliti melakukan kunjungan ulang pada hari14. Responden yang pada hari-14 belum mengalami kesembuhan dari diare tidak diikutsertakan dalam analisis data.

Analisis data menggunakan program statistik dan dilakukan secara univariat, bivariat dan multivariat. Analisis univariat dilakukan untuk mengidentifikasi gambaran variabel usia anak, status gizi anak, pemberian ASI, tingkat pendidikan ibu, frekuensi defekasi dan durasi diare. Untuk karakteristik responden juga dilakukan uji homogenitas dengan menggunakan Chi-Square.

Analisis bivariat dilakukan untuk melihat perbedaan frekuensi defekasi dan durasi diare pada kedua kelompok dengan menggunakan $t$-test independent. 
Sementara analisis multivariat dilakukan untuk melihat pengaruh faktor perancu (karakteristik responden) terhadap frekuensi defekasi dan durasi diare.

\section{Hasil}

Pengumpulan data dilakukan pada April sampai Mei 2010. Jumlah responden yang berhasil diambil datanya adalah 20 orang untuk kelompok intervensi dan 20 orang untuk kelompok kontrol. Sebagian besar balita yang terlibat berusia 6 sampai 24 bulan, dan memiliki status gizi kurang. Data karakteristik responden tersebut dilakukan uji homogenitas dengan cara chi square. Uji homogenitas yang telah dilakukan menunjukkan bahwa karakteristik kedua kelompok adalah setara (homogen).

Pada tabel 1 memperlihatkan perbedaan frekuensi defekasi dan durasi diare antara kelompok kontrol (tidak diberikan zink dalam penanganan diare, tetapi hanya diberikan cairan rehidrasi oral) dan kelompok intervensi (diberikan zink dan cairan rehidrasi oral dalam penanganan diare akut). Rerata frekuensi defekasi pada kelompok intervensi lebih rendah dibandingkan dengan kelompok kontrol. Hasil analisis bivariat menunjukkan bahwa terdapat perbedaan yang signifikan antara frekuensi defekasi kelompok kontrol dan kelompok intervensi $(p=0,000 ; \alpha=0,05)$.

Tabel 1. Perbedaan Frekuensi Defekasi dan Durasi Diare Kelompok Intervensi dan Kontrol

\begin{tabular}{lccccccccc}
\hline \multirow{2}{*}{ Variabel } & \multicolumn{4}{c}{ Kelompok Intervensi $(\mathbf{n = 2 0})$} & \multicolumn{4}{c}{ Kelompok Kontrol (n=20) } \\
\cline { 2 - 9 } & Mean & SD & SE & $\mathbf{p}$ & Mean & SD & SE & p \\
\hline Frekuensi Defekasi & 5,2 & 0,7 & 0,1 & 0,000 & 6,8 & 0,9 & 0,2 & 0,000 \\
Durasi Diare & 6,3 & 1,1 & 0,2 & 0,000 & 8,6 & 1,3 & 0,2 & 0,000 \\
\hline
\end{tabular}

Begitu juga dengan perbedaan durasi diare pada kedua kelompok. Rerata durasi diare pada kelompok intervensi lebih rendah dibanding dengan kelompok kontrol. Hasil analisis menunjukkan bahwa terdapat perbedaan yang signifikan pada durasi diare antara kelompok kontrol dan kelompok intervensi $(p=0,000 ; \alpha=0,05)$.

Pada penelitian ini juga dianalisis pengaruh karakteristik responden (variabel perancu) terhadap frekuensi defekasi dan durasi diare. Pengaruh variabel perancu tersebut dianalisis dengan menggunakan regresi linier. Pada analisis lebih lanjut peneliti mengidentifikasi bahwa faktor perancu tersebut tidak memenuhi syarat untuk dianalisis secara multivariat terhadap frekuensi defekasi. Akan tetapi, pada hasil uji ditemukan adanya pengaruh antara status gizi anak terhadap durasi diare. Hasil analisis variabel perancu terhadap durasi diare dapat dilihat pada tabel 2 .
Tabel 2 memperlihatkan pengaruh karakteristik responden terhadap durasi diare. Analisis lebih lanjut didapatkan hanya status gizi anak yang mempengaruhi durasi diare $(p=0,009 ; \alpha=0,05)$. Oleh karena itu, berdasarkan hasil analisis regresi linier didapatkan pemodelan yang menunjukkan bahwa pada anak yang mengalami gizi kurang, durasi diare akan berlangsung 1,386 lebih lama sesuai dengan persamaan regresi berikut:

$$
\text { Durasi Diare }=9,747-1,386 \text { gizi anak }
$$

\section{Pembahasan}

Hasil penelitian ini menemukan bahwa terdapat perbedaan yang bermakna antara frekuensi defekasi dan durasi diare pada balita di kelompok intervensi dan kelompok kontrol. Temuan ini sesuai dengan penelitian yang dilakukan Strand, et al. (2002), 
yang menemukan data frekuensi pengeluaran feses pada kelompok intervensi mengalami penurunan 8\% dibandingkan dengan kelompok kontrol. Pada penelitian tersebut, juga diidentifikasi bahwa durasi diare pada anak yang mendapatkan zink 26\% lebih pendek dibandingkan dengan kelompok plasebo $(p=0,006)$. Sementara itu, Bhatnagar et al. (2004) mengidentifikasi bahwa volume feses pada kelompok intervensi berkurang hingga 25\% dibandingkan dengan kelompok kontrol.

Hal serupa juga ditemukan pada hasil penelitian Lukacik, Thomas, dan Aranda (2007) yang mencatat bahwa anak yang mendapatkan zink mengalami penurunan durasi diare $15,5 \%$ dibandingkan dengan kelompok kontrol. Data tersebut menunjukkan bahwa pemberian zink selama diare akut menyebabkan pengurangan pengeluaran/ frekuensi tinja dan memiliki efek manfaat yang signifikan dalam alur klinis diare akut.

Selain itu, Hidayat (1997) juga menemukan bahwa adanya penurunan risiko berlanjutnya diare pada kelompok anak yang mendapat suplementasi zink (RR 0,89; 95\% CI:0,82-0,97). Penurunan durasi diare sebesar $11 \%$ ini mempunyai arti yang cukup penting dalam menurunkan risiko terjadinya dehidrasi dan malnutrisi akibat diare.
Menurut Indriani dan Asri (2007), pada beberapa penelitian yang dilakukan di rumah sakit untuk mengukur dampak pemberian zink terhadap keluaran feses, didapatkan hasil terjadinya penurunan keluaran feses antara 18-59\% pada kelompok intervensi dibandingkan dengan kelompok kontrol. Pengaruh terapeutik zink tersebut tidak berbeda secara signifikan walaupun terdapat perbedaan usia dan status nutrisi anak yang diukur secara antropometri. Hasil serupa juga ditemukan oleh Lukacik, Thomas, dan Aranda (2007), yang membuktikan bahwa dari 18,8\% anak yang mendapatkan suplemen zink dilaporkan 12,5\% mengalami penurunan rata-rata frekuensi defekasi.

Peningkatan frekuensi defekasi disertai volume tinja yang banyak selama diare disebabkan karena terjadinya peningkatan kandungan air akibat ketidakseimbangan fungsi usus dalam proses penyerapan substrat organik dan air. Jika terjadi secara terus menerus maka anak dapat mengalami dehidrasi. Oleh karena itu, diare harus dihentikan tidak hanya dengan menggantikan cairan yang hilang akan tetapi dengan memperbaiki kondisi usus. Pemberian cairan rehidrasi oral saja tidak cukup signifikan dalam menurunkan frekuensi defekasi, sehingga perlu ditambahkan zink sebagai regimen terapi (Lukacik, Thomas,\& Aranda, 2008).

Tabel 2. Hasil Analisis Bivariat antara Karakteristik Responden dengan Durasi Diare

\begin{tabular}{lccccc}
\hline \multicolumn{1}{c}{ Variabel } & n & Mean & SD & SE & p \\
\hline Usia Anak & & & & & \\
a. 6-24 bulan & 26 & 7,4 & 1,8 & 0,4 & 0,836 \\
b. $>$ 24 bulan & 14 & 7,5 & 1,4 & 0,4 & \\
Pemberian ASI & & & & 0,4 & 0,026 \\
a. Ya & 9 & 6,3 & 1,3 & 0,4 & \\
b. Tidak & 17 & 7,9 & 1,8 & & 0,231 \\
Pendidikan Ibu & & & & 0,3 & \\
a. Pendidikan Dasar & 23 & 7,7 & 1,4 & & 0,04 \\
b. Pendidikan Lanjut & 17 & 7,1 & 1,9 & & \\
& & & & 0,3 & \\
Status Gizi Anak & 23 & 8,0 & 1,6 & 0,3 & \\
a. Gizi Kurang & 17 & 6,6 & 1,3 & & \\
b. Gizi Baik & & & & & \\
\hline
\end{tabular}


Terjadinya penurunan frekuensi defekasi dan pengurangan volume tinja secara otomatis juga akan memperpendek durasi diare atau mencegah berlanjutnya diare.

Zink merupakan komponen yang memiliki banyak enzim yang memainkan peranan dalam metabolisme asam nukleat dan sintesis protein, serta untuk perbaikan struktur dan fungsi membran. Diare bisa menyebabkan hilangnya zink dalam tubuh. Beberapa penelitian suplementasi zink dalam jumlah besar telah menunjukkan berkurangnya insiden diare akut dan persisten pada bayi dan anak-anak secara bermakna. Meningkatnya status zink pada populasi tersebut juga berhubungan dengan meningkatnya immunokompeten dan kadar aktivitas (Irwanto, Rohim, \& Sudarmo, 2002).

Sebagian besar diare akut yang terjadi pada anakanak di negara berkembang adalah diare infeksi. Zink mempunyai efek terhadap beberapa enterosit dan sel-sel imun yang berinteraksi dengan agen infeksius pada diare, mampu menstabilkan struktur membran dan memodifikasi fungsi membran dengan cara berinteraksi dengan oksigen, nitrogen dan ligan sulfur makro molekul hidrofilik, serta aktifitas antioksidan. Zink juga mencegah dilepaskannya histamin oleh sel mast dan respon kontraksi serta sekretori terhadap histamin dan serotonin pada usus sehingga dapat mencegah peningkatan permeabilitas endotel yang diprakarsai oleh TNF-a yang juga merangsang kerusakan permeabilitas lapisan endotel usus. Zink mampu merangsang pertahanan imun, serta mengurangi efek yang merugikan akibat aktivasi sel imun pada lapisan endotel usus (Armin, 2005).

Kemanjuran suplementasi zink dalam mempengaruhi durasi diare terjadi dengan memperbaiki atau meningkatkan penyerapan air dan elektrolit melalui intestin serta mempercepat regenerasi epitel usus. Peningkatan level enzim enterosit menyebabkan perpindahan zink ke enterosit serta respon imun yang kuat yang akan meningkatkan ketahanan usus terhadap kuman patogen. Keberhasilan pengobatan dengan zink secara umum berkon- tribusi terhadap penurunan volume cairan dalam usus halus dan merangsang penyerapan ion sodium (Lukacik, Thomas, \& Aranda, 2008).

Sebagian besar diare yang terjadi pada anak disebabkan oleh virus. Oleh karena itu, diare biasanya tak berlangsung lama, hanya beberapa hari (34 hari) dan dapat sembuh sendiri tanpa pengobatan (selflimiting disease). Anak akan sembuh kembali setelah enterosit usus yang rusak diganti oleh enterosit baru dan yang normal serta sudah matang (mature), sehingga dapat menyerap dan mencerna cairan serta makanan dengan baik (Irwanto, Rohim, \& Sudarmo, 2002).

Anak dengan diare akan mengalami defisiensi berbagai mikronutrien, termasuk zink, sehingga suplementasi zink pada anak dengan diare tersebut dapat menurunkan morbiditas dan mortalitas akibat diare. Zink mempunyai peranan dalam metabolism enzim, poli-ribosom, membran sel, dan fungsi seluler. Kehilangan zink melalui saluran cerna akibat diare akan memperburuk defisiensi zink yang memang sudah ada (Indriani \& Sari, 2007).

Berdasarkan hal tersebut, peneliti menganalisis bahwa penggunaan zink selama diare akut diperkirakan akan mempengaruhi fungsi imun atau fungsi dan struktur intestinal serta proses pemulihan epitel selama diare, sehingga akan mencegah diare lebih lanjut atau mempercepat proses penyembuhan.

Hasil analisis terhadap variabel perancu (status gizi anak), menunjukkan bahwa terdapat hubungan yang bermakna antara status gizi anak dengan durasi diare akut. Kondisi kurang gizi merupakan salah satu faktor yang yang dapat meningkatkan insiden beratnya penyakit serta lamanya diare berlangsung. Beratnya penyakit, lamanya, dan resiko kematian karena diare akan meningkat pada anak-anak dengan kurang gizi dan anak yang menderita gizi buruk. Gangguan gizi yang terjadi sebelum sakit akan diperberat oleh berkurangnya intake makanan, meningkatnya kebutuhan, serta kehilangan nutrien melalui usus (saluran cerna), 
sehingga berkontribusi terhadap lamanya diare berlangsung.

Hal tersebut di atas sesuai dengan penelitian yang dilakukan oleh Hidayat (1997), menyatakan bahwa anak dengan status gizi kurang yang mendapatkan suplemen zink (kelompok intervensi) mempunyai risiko diare berlanjut 0,92 kali lebih kecil dibandingkan dengan kelompok kontrol, tetapi tidak bermakna secara statistik (95\% CI: 0,79-1,09). Hal tersebut diperkuat oleh pernyataan WHO (2009), yang menyebutkan bahwa gangguan gizi dapat menyebabkan diare menjadi lebih parah, lebih lama dan lebih sering terjadi dibandingkan dengan kejadian diare pada anak yang tidak menderita gangguan gizi. Malnutrisi atau gangguan imunologi pada anak-anak lebih rentan dan cenderung berkontribusi terhadap keparahan diare. Hal ini jelas sekali, karena gizi merupakan elemen yang sangat penting dalam menjaga kesehatan, terutama tumbuh kembang balita, meningkatkan daya tahan tubuh dan proses penyembuhan suatu penyakit.

\section{Kesimpulan}

Hasil penelitian ini menemukan bahwa zink efektif dalam mengatasi diare akut pada balita di salah satu puskesmas di Kalimantan Barat, dengan cara mengurangi frekuensi defekasi dan memperpendek durasi diare. Selain itu, ditemukan hubungan yang signifikan antara status gizi anak dan pemberian ASI dengan durasi diare, namun tidak ada hubungan antara usia anak dan tingkat pendidikan ibu dengan durasi diare. Analisis hubungan karakteristik responden yaitu usia anak, tingkat pendidikan ibu, status pemberian ASI, dan status gizi dengan frekuensi defekasi juga menunjukkan tidak ada hubungan yang signifikan. Uji regresi linier menemukan bahwa variabel yang paling berpengaruh terhadap durasi diare adalah status gizi anak.

Berdasarkan hasil penelitian ini, disarankan bahwa pemerintah kota dan petugas puskesmas dapat mensosialisasikan penggunaan zink dan mengimplementasikan program pemerintah dan anjuran WHO terkait dengan penatalaksanaan diare akut menggunakan zink (WK, SW, DW).

\section{Referensi}

Armin, S. A. (2005). Zat gizi mikro zink, dari aspek molekuler sampai pada program kesehatan masyarakat. Diperoleh dari http://www. akademik.unsri.ac.id/download/ journal/files / medhas/5-.pdf.

Bhatnagar, S., \& Natchu, U.C.M. (2004). Zinc in child health and disease. Indian Journal of Pediatric, 71 (11), 991-995.

Departemen Kesehatan RI. (2007). Pedoman pengobatan dasar di puskesmas. Diperoleh dari http://www.depkes.go.id/downloads/doen2008/ puskesmas_2007.pdf.

Hidayat, A. (1997). Pengaruh pemberian seng terhadap diare akut anak balita (Disertasi, tidak dipublikasikan). Program Pascasarjana Universitas Indonesia, Jakarta.

Hockenberry, M.J., \& Wilson, D. (2009). Wong's Essentials of pediatric nursing. St. Louis, Missouri: Mosby Elsevier.

Indriani, R., \& Asri, E.K. (2007). Formulasi oralit baru dan suplementasi zink dalam penanganan diare pada anak. InfoPOM, 8 (3), 4-5.ISSN 18299334.

Irwanto, Rohim, A., \& Sudarmo, S.M. (2002). Diare akut pada anak. Dalam: Ilmu penyakit anak: Diagnosa dan penatalaksanaan. Jakarta: Penerbit Salemba Medika.

Ladinsky, M., Duggan, A., Santosham, M., \& Wilson, M. (2000). The World Health Organization oral rehydration solution in US pediatric practice: A randomized trial to evaluate parent satisfaction. Arch Pediatr Adolesc Med, 154 (7), 700-705. Doi: 10.1001/archpedi.154.7.700.

Lukacik, M., Thomas, R.L., \& Aranda, J.V. (2008). A meta-analysis of the effects of oral zinc in the treatment of acute and persistent diarrhoea. Pediatrics, 121 (2), 326-336.

Strand, et al. (2002). Effectiveness and efficacy of zinc for the treatment of acute diarrhea in young children. Pediatrics, 109 (5), 898-903. 